\title{
Descriptive characteristics of the cohort of workers from the Siberian Group of Chemical Enterprises (SGCE)
}

\author{
Andrey Karpov ${ }^{1, *}$, Ravil Takhauov ${ }^{1}$, Andrey Zerenkov ${ }^{1}$, Yuriy Dolgopolov ${ }^{2}$, \\ Konstantin Izmestev ${ }^{2}$, Aleksey Blinov ${ }^{1}$, Lydia Zablotska ${ }^{3}$ \\ ${ }^{1}$ Seversk Biophysical Research Center of the Russian Federal Medical and Biological Agency, \\ Seversk, Russia \\ ${ }^{2}$ Siberian Group of Chemical Enterprises of State Corporation Rosatom, Seversk, Russia \\ ${ }^{3}$ School of Medicine, University of California, San Francisco, USA
}

Siberian Group of Chemical Enterprises (SGCE) is a large complex for production of nuclear fuel which includes multiple processing facilities, including isotope separation and sublimation. The Isotope separation plant and the Sublimation plant were put into commercial operation in 1953 and in 1954, respectively. They produce uranium enriched by isotope U-235 and uranium hexafluoride. Both natural and regenerated uranium are used as raw materials.

Systematic monitoring of uranium alpha-emitting radionuclides in the SGCE employees was initiated in the mid-1950s by specialized biophysical laboratory using the indirect method based on the radiochemical analysis of biological samples. Biophysical examination of the uranium body burden was conducted once per year.

The cohort of SGCE workers potentially exposed to uranium includes all employees who were hired during January 1, 1950-December 31, 2010 and worked for at least 1 year ( $\sim 3,500$ workers). Workers from this group may have been exposed to both external radiation (approximately $60 \%$ ) and to internal radiation from incorporated plutonium. Table 1 shows descriptive characteristics of SGCE employees potentially exposed to uranium. Follow up was conducted through 2014 through a specialized medical registry for SGCE employees (vital status known for $\sim 75 \%$ ). Table 2 shows the distribution of uranium group employees by uranium content in urine and cumulative dose of external exposure.

Table 1. Descriptive characteristics of SGCE workers potentially exposed to uranium

\footnotetext{
*Corresponding author: sbnc@fmbamail.ru
} 
first employed 1950 to 2010 .

\begin{tabular}{|c|c|c|c|c|c|c|c|}
\hline Variable & Sex & $\begin{array}{l}\text { Radio- } \\
\text { chemical } \\
\text { plant }\end{array}$ & $\begin{array}{c}\text { Plutonium } \\
\text { plant }\end{array}$ & $\begin{array}{c}\text { Plutonium } \\
\text { plant }\end{array}$ & $\begin{array}{c}\text { Sublimate } \\
\text { plant }\end{array}$ & $\begin{array}{l}\text { Support } \\
\text { facility }\end{array}$ & Total \\
\hline \multirow{2}{*}{$\begin{array}{l}\text { Total number of } \\
\text { employees }\end{array}$} & $\mathrm{M} / \mathrm{F}$ & $154 / 58$ & $1,664 / 464$ & $311 / 133$ & $506 / 122$ & $89 / 53$ & \\
\hline & Total & 212 & 2,128 & 444 & 628 & 142 & 3,554 \\
\hline \multirow{2}{*}{$\begin{array}{l}\text { Outpatient } \\
\text { examination }\end{array}$} & $\mathrm{M} / \mathrm{F}$ & $35 / 7$ & $1,349 / 93$ & $219 / 108$ & $315 / 78$ & $50 / 35$ & \\
\hline & Total & 42 & 1,442 & 327 & 393 & 85 & 2,289 \\
\hline \multirow{2}{*}{$\begin{array}{l}\text { Hospital } \\
\text { examination }\end{array}$} & $\mathrm{M} / \mathrm{F}$ & $124 / 52$ & $859 / 192$ & $70 / 18$ & $269 / 56$ & $53 / 19$ & \\
\hline & Total & 176 & 1,051 & 88 & 325 & 72 & 1,712 \\
\hline \multirow{2}{*}{$\begin{array}{l}\text { Uranium body } \\
\text { burden }\end{array}$} & $\mathrm{M} / \mathrm{F}$ & $25 / 6$ & $389 / 97$ & $41 / 21$ & $94 / 9$ & $13 / 5$ & \\
\hline & Total & 31 & 486 & 62 & 103 & 18 & 700 \\
\hline \multirow{2}{*}{$\begin{array}{l}\text { Monitored for } \\
\text { external exposure }\end{array}$} & $\mathrm{M} / \mathrm{F}$ & $199 / 51$ & $975 / 168$ & $85 / 12$ & $418 / 87$ & $56 / 28$ & \\
\hline & Total & 250 & 1,143 & 97 & 505 & 84 & 2,079 \\
\hline $\begin{array}{l}\text { Cancer patients: } \\
\text { total number }(\%)\end{array}$ & Total & $\begin{array}{c}32 \\
(15.1)\end{array}$ & $\begin{array}{c}289 \\
(13.6)\end{array}$ & $\begin{array}{c}99 \\
(22.3)\end{array}$ & $\begin{array}{c}116 \\
(18.5)\end{array}$ & $\begin{array}{c}28 \\
(19.7)\end{array}$ & $\begin{array}{c}564 \\
(15.9)\end{array}$ \\
\hline
\end{tabular}

Table 2. Distribution of SGCE workers potentially exposed to uranium by categories of uranium content in urine and by cumulative dose of external exposure.

\begin{tabular}{|c|c|c|c|c|c|c|c|c|c|}
\hline \multirow{2}{*}{ Variable } & \multicolumn{9}{|c|}{ Uranium content in urine $(\mathbf{k B q})$} \\
\hline & \multicolumn{2}{|c|}{$<0.046$} & \multicolumn{2}{|c|}{$0.046-0.74$} & \multicolumn{2}{|c|}{$>0.74-1.48$} & \multicolumn{2}{|c|}{$>1.48-3.70$} & $>3.70$ \\
\hline Male & \multicolumn{2}{|c|}{883} & \multicolumn{2}{|c|}{1,395} & \multicolumn{2}{|c|}{133} & & 47 & 30 \\
\hline Female & \multicolumn{2}{|c|}{256} & \multicolumn{2}{|l|}{448} & \multicolumn{2}{|c|}{21} & & 7 & 12 \\
\hline Total & \multicolumn{2}{|c|}{1,139} & \multicolumn{2}{|l|}{$\mathbf{1 , 8 4 3}$} & \multicolumn{2}{|c|}{154} & & 54 & 42 \\
\hline \multirow{2}{*}{ Index } & \multicolumn{9}{|c|}{ Cumulative Dose of External Exposure (mSv) } \\
\hline & 0 & $>0-50$ & $>50-150$ & $>1$ & $50-200$ & $>200$ & 300 & $>300-500$ & $>500-1,000$ \\
\hline Male & 1,068 & 722 & 408 & & 113 & 1( & & 152 & 87 \\
\hline Female & 491 & 189 & 89 & & 25 & 2 & & 11 & 2 \\
\hline Total & 1,559 & 911 & 497 & & 138 & 10 & & 163 & 89 \\
\hline
\end{tabular}

In summary, we presented a first description of the cohort of workers employed at the SGCE who were exposed to a complex combination of external and internal irradiation and potentially could have been exposed to uranium. The electronic database contains detailed information on occupational activities including the information on the measured doses of external exposure and dynamics of their accumulation, as well as the data on biophysical studies for detection of uranium body burden. The cohort has been followed up for mortality and cancer incidence for over 65 years and presents a unique opportunity for conducting research on the medical and biological effects of low-dose chronic radiation exposure. This cohort of SGCE employees is uniquely suited for research on the effects of the long-term low-dose occupational radiation exposures. 